\title{
Using mapping studies as the basis for further research - A participant-observer case study
}

\author{
Barbara A. Kitchenham, David Budgen and O. Pearl Brereton \\ School of Computing and Mathematics \\ Keele University \\ Staffordshire \\ ST5 5BG, UK \\ \{b.a.kitchenham,o.p.brereton\}@cs.keele.ac.uk \\ Durham University \\ South Road, Durham City, \\ DH1 3LE, UK \\ david.budgen@durham.ac.uk
}

\begin{abstract}
Context: We are strong advocates of evidence-based software engineering (EBSE) in general and systematic literature reviews (SLRs) in particular. We believe it is essential that the SLR methodology is used constructively to support software engineering research.

Objective: This study aims to assess the value of mapping studies which are a form of SLR that aims to identify and categorise the available research on a broad software engineering topic.

Method: We used a multi-case, participant observer case study using five examples of studies that were based on preceding mapping studies. We also validated our results by contacting two other researchers who had undertaken studies based on preceding mapping studies and by assessing review comments related to our follow-on studies.
\end{abstract}

Results: Our original case study identified eleven unique benefits that can accrue from basing research on a preceding mapping study of which only two were case specific. We also identified nine problems associated with using preceding mapping studies of which two were case specific. These results were consistent with the information obtained from the validation activities. We did not find an example of an independent research group making use of a mapping study produced by other researchers.

Conclusions: Mapping studies can save time and effort for researchers and provide baselines to assist new research efforts. However, they must be of high quality in terms of completeness and rigour if they are to be a reliable basis for follow-on research.

Keywords: case study; systematic literature review; mapping studies; software engineering 


\section{Introduction}

In 2004-5, Kitchenham, Dybå and Jørgensen wrote three papers suggesting that the concept of evidence-based practice, (as initially developed in medicine, and subsequently adopted by many different disciplines including economics, psychology, social science and most health care disciplines) should be adopted in software engineering ([1], [2], [3]). By analogy with medicine, they suggested that evidencebased software engineering (EBSE) should be concerned with the aggregation of empirical evidence and should use systematic literature reviews (SLRs) as a methodology for performing unbiased aggregation of empirical results. Based on the 5 stages in evidence-based medicine, Kitchenham et al. [3] suggested equivalent stages for EBSE. Stages 1 to 4 are to:

1. construct an answerable question;

2. track down evidence to answer the question;

3. critically appraise the evidence, and

4. use the evidence to address the question.

Stage 5 is rather different in nature. It is about seeking ways to improve the way in which we undertake evidence-based software engineering and provides the rationale for this paper.

One of the main technologies underpinning EBSE is a rigorous procedure for searching research literature called a systematic literature review (SLR). SLRs are secondary studies (i.e. studies that are based on analyzing previous research) used to find, critically evaluate and aggregate all relevant research papers (referred to as primary studies) on a specific research question or research topic. The methodology is intended to ensure that the literature review is unbiased, rigorous and auditable. The basic SLR methodology is similar, irrespective of the discipline where it is employed; although medical standards emphasize meta-analysis (a means of statistically aggregating the results from different studies of the same phenomena) more than other disciplines (see for example, [4], [5], [6], [7]).

We have been undertaking a program of case study-based research that is aimed at better understanding the role of SLRs in software engineering [8]. This is part of the Evidence-based Practices Informing Computing (EPIC) project, funded by the UK Engineering and Physical Sciences Research Council. In this paper we assess the value that mapping studies (also called scoping reviews) provide to the research community.

Mapping studies use the same basic methodology as SLRs but aim to identify and classify all research related to a broad software engineering topic rather than answering questions about the relative merits of competing technologies that conventional SLRs address [9]. They are intended to provide an overview of a topic area and identify whether there are subtopics with sufficient primary studies to conduct conventional SLRs and also to identify subtopics where more primary studies are needed. In our experience, there are a relatively large number of mapping studies [10], but relatively little discussion of their value as a research tool (see Section 3). Since mapping studies do not discuss the outcomes of the primary studies their relevance to practitioners is limited, so if they are to be of value at all they must deliver value to the research community. Thus, the overall goal of this paper to explore the value of mapping studies as a research tool and in particular to investigate how mapping studies contribute to further research. 
We discuss the difference between Mapping Studies and SLRs and some examples of mapping studies and follow-on research activities in section 2. In Section 3, we review related research. In Section 4 we present the methodology for our case study and for two additional activities we undertook to validate our initial results. Section 5 presents our results and we answer our research questions in Section 6. The conclusions are presented in Section 7.

A short version of this paper was presented at the EASE 2010 Conference [11]. This paper has extended the discussion of related work and also reports additional research aimed at validating the original results.

\section{Mapping Studies and Systematic Literature Reviews}

This section explains the differences between mapping studies and SLRs. We also present some examples of mapping studies and identify some benefits and problems with mapping studies.

\subsection{The difference between a mapping study and a SLR}

A standard systematic literature review is driven by a very specific research question that can be answered by empirical research, for example "Are algorithmic cost models more accurate than expert judgement-based estimates?” ([12]). This research question drives the identification of appropriate primary studies (searching and inclusion/exclusion activities), informs the data extraction process applied to each included primary study, and determines the aggregation of the extracted data.

In contrast a mapping study reviews a broader software engineering topic and classifies the primary research papers in that specific domain. The research questions for such a study are quite high level and include issues such as which sub-topics have been addressed, what empirical methods have been used, and what sub-topics have sufficient empirical studies to support a more detailed systematic review ([9], [13]). Thus, mapping studies can be of great potential importance to software engineering researchers by providing an overview of the literature in specific topic areas. Although at the extreme, mapping studies and systematic reviews have rather different goals, there is often an overlap (see for example, [14] which although the paper is mainly a mapping study also includes an assessment of the outcomes of some papers in one of the categories). Some systematic reviews include a classification system to organise relevant literature followed by a more detailed description of the research within each category (see for example [15] which has mapping study-like research questions but performs a series of aggregations for sets of papers in various different categories).

One important difference is that a conventional SLR makes an attempt to aggregate the primary studies in terms of the research outcomes and investigates whether those research outcomes are consistent or contradictory. In contrast, a mapping study usually aims only to classify the relevant literature and aggregates studies with respect to the defined categories. The categories used in a mapping study are usually based on publication information (authors' names, authors' affiliations, publication source, publication type, publication date, etc.) and/or information about the research methods used. Thus, mapping studies often have a relative large number of research questions, compared with SLRs. Furthermore, they do not explicitly consider or aggregate the outcomes of the primary studies. Another important difference is the scope of the 
studies: mapping studies usually relate to a broad topic area such as requirements analysis or software cost estimation, whereas an SLR usually relates to much more detailed topic area such as requirements specification methods or the techniques used to construct software cost estimation models. As a result, mapping studies usually include far more primary studies than SLRs. Differences between mapping studies and conventional SLRs are summarised in Table 1 based on our experience of software engineering mapping studies. These may differ from mapping studies in other disciplines. For example, software engineering mapping studies often limit the scope of their searches in various ways such as only selecting journal papers (e.g. [16]) or only searching a specific set of sources (e.g. [17], [18]), or only searching papers published in specific years (e.g. [14]). We have not found this practice reported in methodological text books used in other disciplines (e.g. [6]). However, the implications are that a mapping study may be auditable but not necessarily complete.

Table 1 Differences between mapping studies and conventional SLRs

\begin{tabular}{|c|c|c|}
\hline SLR Elements & Mapping Study & SLR \\
\hline Goals & $\begin{array}{l}\text { Classification and } \\
\text { thematic analysis of } \\
\text { literature on a software } \\
\text { engineering topic }\end{array}$ & $\begin{array}{l}\text { Identifying best practice with } \\
\text { respect to specific procedures, } \\
\text { technologies, methods or tools by } \\
\text { aggregating information from } \\
\text { comparative studies. }\end{array}$ \\
\hline Research Question & $\begin{array}{l}\text { Generic - related to } \\
\text { research trends. Of the } \\
\text { form: which researchers, } \\
\text { how much activity, what } \\
\text { type of studies etc. }\end{array}$ & $\begin{array}{l}\text { Specific - related to outcomes of } \\
\text { empirical studies. } \\
\text { Of the form: Is technology/method } \\
\text { A better or not than B? }\end{array}$ \\
\hline Search process & Defined by topic area. & $\begin{array}{l}\text { Defined by research question } \\
\text { which identifies the specific } \\
\text { technologies being investigated. }\end{array}$ \\
\hline Scope & $\begin{array}{l}\text { Broad -all papers related } \\
\text { to a topic area are } \\
\text { included but only } \\
\text { classification data about } \\
\text { these are collected }\end{array}$ & $\begin{array}{l}\text { Focused - only empirical papers } \\
\text { related to a specific research } \\
\text { question are included and detailed } \\
\text { information about individual } \\
\text { research outcomes is extracted } \\
\text { from each paper. }\end{array}$ \\
\hline $\begin{array}{l}\text { Search strategy } \\
\text { requirements }\end{array}$ & $\begin{array}{l}\text { Often less stringent if } \\
\text { only research trends are of } \\
\text { interest, for example } \\
\text { authors may search only a } \\
\text { targeted set of } \\
\text { publications, restrict } \\
\text { themselves to journal } \\
\text { papers, or restrict } \\
\text { themselves to one or two } \\
\text { digital libraries. }\end{array}$ & $\begin{array}{l}\text { Extremely stringent - all relevant } \\
\text { studies should be found. Usually } \\
\text { SLR teams need to use techniques } \\
\text { other than simply searching data } \\
\text { sources, such as looking at the } \\
\text { references in identified primary } \\
\text { studies and/or approaching } \\
\text { researchers in the field to find out } \\
\text { whether they are undertaking new } \\
\text { research in the area. }\end{array}$ \\
\hline Quality evaluation & $\begin{array}{l}\text { Not essential. Also } \\
\text { complicated by the } \\
\text { inclusive nature of the } \\
\text { search which can include } \\
\text { theoretical studies as well }\end{array}$ & $\begin{array}{l}\text { Important to ensure that results are } \\
\text { based on best quality evidence. }\end{array}$ \\
\hline
\end{tabular}




\begin{tabular}{|l|l|l|}
\hline & $\begin{array}{l}\text { as empirical studies of all } \\
\text { types making the quality } \\
\text { evaluation of primary } \\
\text { studies complicated. }\end{array}$ & \\
\hline Results & $\begin{array}{l}\text { A set of papers related to } \\
\text { a topic area categorised in } \\
\text { a variety of dimensions } \\
\text { and counts of the number } \\
\text { of papers in various } \\
\text { categories }\end{array}$ & $\begin{array}{l}\text { The outcomes of the primary } \\
\text { studies are aggregated to answer } \\
\text { the specific research question(s), } \\
\text { possibly with qualifiers (e.g. } \\
\text { results apply to novices only). }\end{array}$ \\
\hline
\end{tabular}

\subsection{Examples of Mapping Studies in Software Engineering}

An initial assessment of the value of mapping studies in software engineering can be made by reviewing some example mapping studies. Sjøberg et al. [17] performed a mapping study that identified 103 papers describing human-centric experiments and quasi-experiments published in 13 leading journals and conferences. This set of papers has been used in numerous subsequent systematic reviews that have investigated aspects of empirical software engineering (i.e. [19], [20], [21], [22] and [23]). This example illustrates how mapping studies provide a body of research that researchers can use to undertake more detailed SLRs. However, the subsequent SLRs were all undertaken by members of the original research team because the list of 103 papers was not published in any of the journal papers.

In contrast to Sjøberg et al.'s study, in a mapping study of software cost estimation papers, Jørgensen and Shepperd [16] cited all the papers found by the study and provided open access to the database holding details about each primary study. The database is available to any interested researchers (www.simula.no/BESTweb) subject to obtaining a user name from Jørgensen.

From the above discussion, a problem with software engineering mapping studies is already clear, i.e. some mapping studies do not report all the identified primary studies (e.g. [24], [25], [26]). In addition some mapping studies do not report the classification for each primary study (i.e. only report aggregations such as the number of primary studies in each category), for example [27]. In two studies, Kitchenham et al. ([28], [10]) identified 12 software engineering mapping studies published between 2004 and June 2008 (excluding the Jørgensen and Shepperd study and Sjøberg et al.'s study) and in only two cases were the primary studies all cited and the classifications clearly linked to the specific studies. This limits the value of the study to other researchers. A common reason for this is space restrictions in conference papers and journals. An interesting example of how to avoid this problem is found in the paper by Neto et al. [29] where details about all the primary studies were included in an appendix published as a Web Extra associated with the specific issue of IEEE Software.

Finally, in order to further illustrate the difference between mapping studies and SLRs, in Table 2, we compare Jørgensen and Shepperd's mapping study with Kitchenham et al.'s SLR [30], using on the criteria adopted in Table 1 plus an additional criterion "Recommendations". Note Jørgensen and Shepperd's research questions have been shortened to save space. Table 2 demonstrates quite clearly the difference between research questions for a mapping study and an SLR. Jørgensen and Shepperd's research 
questions relate to publication details and the research methods used, whereas Kitchenham et al.'s main research questions address the outcomes of the comparative studies and what could have influenced those outcomes. Both these studies adopted a broad search but Jørgensen and Shepperd restricted themselves to journal papers and thus would have found only two of the 10 papers identified by Kitchenham et al. As mentioned in Section 2.1, mapping studies usually include more primary studies than SLRs ([28], [10]), in this case 304 papers compared to 10 papers. In addition, an SLR must be careful to discount duplicate reports of the same study whereas Jørgensen and Shepperd explicitly state that they included different papers discussing the same study. As is common in mapping studies Jørgensen and Shepperd did not undertake a quality evaluation of the primary studies. Finally, Jørgensen and Shepperd provided advice only to researchers whereas Kitchenham et al. provided advice not only to researchers but also to cost estimators as to in what circumstances a cross-company model would be acceptable and in what circumstances a within company model would be the best option.

Table 2 Differences between Jørgensen and Shepperd'mapping study [15] and Kitchenham et al.'s SLR [30]

\begin{tabular}{|c|c|c|}
\hline SLR process & Mapping Study & SLR \\
\hline Goals & $\begin{array}{l}\text { The improvement of cost } \\
\text { estimation research. }\end{array}$ & $\begin{array}{l}\text { To assess whether contradictory } \\
\text { results relating to the accuracy } \\
\text { of within and cross-company } \\
\text { estimates could be reconciled. }\end{array}$ \\
\hline Research Question & $\begin{array}{l}\text { RQ1: What journals include } \\
\text { papers on software cost } \\
\text { estimation? } \\
\text { RQ2: Are software cost } \\
\text { estimation researchers aware } \\
\text { of the breadth of sources? } \\
\text { RQ3: Which journals publish } \\
\text { most papers? } \\
\text { RQ4: How easy is it to find } \\
\text { relevant papers? } \\
\text { RQ4: Who are long term } \\
\text { researchers and what impact } \\
\text { have they had? } \\
\text { RQ6: What topics are most } \\
\text { investigated? } \\
\text { RQ7: What are the most } \\
\text { investigated estimation } \\
\text { methods? } \\
\text { RQ8: What the most } \\
\text { frequently used research } \\
\text { methods? }\end{array}$ & $\begin{array}{l}\text { Main questions: } \\
\text { Q1: What evidence is there that } \\
\text { cross-company estimates are not } \\
\text { significantly different from } \\
\text { within-company estimation } \\
\text { models for predicting effort for } \\
\text { software/Web projects? } \\
\text { Q2 Which characteristics of the } \\
\text { study data sets and data analysis } \\
\text { methods used in the study affect } \\
\text { the outcome of within-company } \\
\text { and cross-company effort } \\
\text { estimation studies? } \\
\text { Secondary question: } \\
\text { Q3 Which experimental } \\
\text { procedure is most appropriate } \\
\text { for studies comparing within- } \\
\text { company and cross-company } \\
\text { effort estimation accuracy } \\
\text { studies? }\end{array}$ \\
\hline Search process & $\begin{array}{l}\text { Issue by issue manual search } \\
\text { of "more than } 100 \text { potentially } \\
\text { relevant peer reviewed } \\
\text { journals", resulting in } 304 \\
\text { papers. }\end{array}$ & $\begin{array}{l}\text { Automated search accompanied } \\
\text { by checking the references of } \\
\text { primary studies for other } \\
\text { candidate primary studies and } \\
\text { approaching known researchers } \\
\text { asking whether they were }\end{array}$ \\
\hline
\end{tabular}




\begin{tabular}{|c|c|c|}
\hline & & $\begin{array}{l}\text { currently undertaking further } \\
\text { studies. } 10 \text { relevant papers were } \\
\text { identified although three were } \\
\text { rejected during analysis because } \\
\text { they used the same datasets as } \\
\text { other papers for both within and } \\
\text { cross-project data sets and were } \\
\text { therefore considered duplicate } \\
\text { results. }\end{array}$ \\
\hline Scope & $\begin{array}{l}\text { All papers on the topic of } \\
\text { software cost estimation } \\
\text { excluding only pure } \\
\text { discussion and opinion } \\
\text { papers. }\end{array}$ & $\begin{array}{l}\text { All papers comparing the } \\
\text { accuracy of cost estimation } \\
\text { models applied to a projects of a } \\
\text { particular company built either } \\
\text { on the data from that company } \\
\text { or on the data from a data base } \\
\text { including projects from many } \\
\text { companies. This excluded } \\
\text { comparisons based on the } \\
\text { accuracy of published cost } \\
\text { models and the accuracy of a } \\
\text { within company model. }\end{array}$ \\
\hline $\begin{array}{l}\text { Search strategy } \\
\text { requirements }\end{array}$ & $\begin{array}{l}\text { Restricted to journal papers. } \\
\text { The journals were selected by } \\
\text { the researchers based on their } \\
\text { personal experience and } \\
\text { knowledge of where relevant } \\
\text { papers had been published. }\end{array}$ & $\begin{array}{l}\text { Included conference and journal } \\
\text { papers. Also included additional } \\
\text { searches based on primary study } \\
\text { references and approaching } \\
\text { individual researchers. }\end{array}$ \\
\hline Quality evaluation & None & $\begin{array}{l}\text { Yes. } 5 \text { questions related to study } \\
\text { quality and } 4 \text { related to } \\
\text { reporting quality. }\end{array}$ \\
\hline Results & $\begin{array}{l}\text { Counts and/or graphics } \\
\text { showing the number of } \\
\text { papers in different categories } \\
\text { determined by the research } \\
\text { questions. }\end{array}$ & $\begin{array}{l}\text { Tables identifying the outcome } \\
\text { of each study. These showed } 3 \\
\text { papers that found cross- } \\
\text { company estimates no worse } \\
\text { than within-company estimates, } \\
\text { four studies that found cross- } \\
\text { company models significantly } \\
\text { worse than within-company } \\
\text { studies. No studies found cross- } \\
\text { company estimates significantly } \\
\text { better than within company } \\
\text { estimates. Tables also } \\
\text { summarised study related } \\
\text { factors and study methods. }\end{array}$ \\
\hline Recommendations & $\begin{array}{l}\text { Four recommendations to } \\
\text { improve primary studies: } \\
\text { Increase breath of search; } \\
\text { Search manually in selected } \\
\text { journals; Investigate methods } \\
\text { used in industry; Consider }\end{array}$ & $\begin{array}{l}\text { Advice to cost estimation users: } \\
\text { Small companies with } \\
\text { specialised products are less } \\
\text { likely to benefit from cross- } \\
\text { company models than large } \\
\text { companies with large projects. }\end{array}$ \\
\hline
\end{tabular}




\begin{tabular}{|l|l|l|}
\hline & how properties of data sets & Advice to researchers: \\
impact results. & $\begin{array}{l}\text { Use similar methods including } \\
\text { more stringent evaluation of } \\
\text { accuracy. } \\
\text { Identify more contextual } \\
\text { information about datasets. }\end{array}$ \\
\hline
\end{tabular}

\section{Related Research}

Three recent papers have discussed the use of mapping studies in software engineering ([9], [13] and [31]).

Petersen et al. [13] compared the methods used in mapping studies and systematic reviews and identified a set of guidelines for mapping studies. They advocate using mapping studies to map all of the literature in a topic area including empirical and nonempirical studies. They discuss the mapping study procedures related to five stages:

1. Definition of Research Questions

2. Conducting the Search for Primary Studies.

3. Screening papers based on Inclusion/Exclusion Criteria

4. Classifying the papers

5. Data Extraction and Aggregation.

The two stages where mapping studies differ most strongly from SLRs are classifying the papers, and data extraction and aggregation. For classifying the type of research, they recommend using a classification system developed by Wieringa et al. [32], which uses six categories:

1. Validation research, that concerns evaluating novel techniques not yet deployed in industry;

2. Evaluation research, that concerns evaluating industrial practice;

3. Solution proposal, that discuss new or revised techniques;

4. Philosophical papers, that structure the field in new ways such as taxonomies;

5. Opinion papers;

6. Experience papers, that discuss how someone did something in practice. They report finding this classification method easy to use.

For aggregating data, Petersen et al. recommend using visualization techniques. They give an example of a bubble plot that allows the distribution of papers to be represented in three dimensions. They suggest that such displays are better than frequency plots because they provide a better overview of the field.

With respect to the value of mapping studies, they point out that a mapping study can, and indeed should, be the first step towards a systematic review. Furthermore they suggest that visual maps may be useful for practitioners: "the visual appeal of systematic maps can summarize and help transfer results to practitioners". With respect to problems they note that it is often not possible to classify papers solely by reading the abstract since abstracts "are often misleading and lack important information".

Budgen et al. [9] discussed 6 mapping studies including two of the mapping studies discussed in this paper ([33], [34]). Their study concentrates on mapping studies that are aimed at mapping empirical studies rather than at mapping the research literature as a 
whole. They suggest that classification of empirical research papers (as opposed to the more general classification of literature proposed by Weiringa et al. [32]) poses a problem particularly for student researchers.

Budgen et al. suggest that benefits of performing mapping studies include:

- Providing a starting point for PhD students who need "to organise and understand the existing research work in a specific domain."

- In the longer term, providing the next generation of researchers with a body of knowledge as the starting point of their research rather than forcing every researcher to start from scratch.

Kitchenham et al. [31] investigated the educational value of mapping studies based on questionnaires given to three postgraduate and three undergraduate students who undertook a mapping study. Their study was closely related to the current case study because three of the mapping studies discussed in their paper are also discussed in this paper ([33], [34] and the Visualization study referred to in Table 3). The study identified a number of educational benefits of mapping studies:

- $\quad$ They teach students how to search the literature and organize the results of searches.

- $\quad$ For PhD students, they provide a valuable means of initiating their research.

- $\quad$ They provide students with reusable research skills.

- They give a good overview of the literature

- $\quad$ They are challenging but enjoyable.

The main problem was that they require considerable effort.

\section{Method}

\subsection{The Research Question}

The research question addressed by this case study is: "How do mapping studies contribute to further research?” In order to address the research question we consider two sub-questions:

- RQ.S1 What are the advantages and disadvantages of basing research on a previous mapping study?

- $\quad$ RQ.S2 What makes a mapping study suitable for supporting further research activities?

The first sub-question addresses the general value of the research method. It relates directly to our overall research question but acknowledges that there may be associated disadvantages to the method that need to be identified. The second sub-question addresses the issue of determining whether a specific mapping study is likely to be useful to other researchers.

\subsection{Research Method}

We used a case study methodology to investigate our research questions [35]. In this context, our interpretation of "case" is a research activity following on directly from a preceding mapping study. We considered a total of five cases, so the study is a multiple- 
case study. We ourselves were involved in many of the studies, so the case study is also a participant-observer study.

To provide a different viewpoint on our case study results, we followed up our case study with two further validation activities:

- We assessed the review comments we had received from the journals/conferences when we submitted reports of our follow-on activities for publication, to see whether any of the criticisms were related to the problem of following-on from a previous mapping study.

- We contacted two researchers who had undertaken follow-on activities after undertaking a mapping study and asked them to complete a questionnaire derived from the case study results.

\subsection{Case Selection and Case Study Roles and Procedures}

The cases were selected for convenience. The individual cases comprise follow-on activities undertaken at Durham University and overseen by Budgen, plus two followon activities undertaken as part of an EPIC study and overseen by Kitchenham. These represented all the follow-on activities undertaken by EPIC researchers.

Kitchenham was responsible for:

- Circulating questionnaires to staff involved in two follow-on studies undertaken as part of the EPIC project.

- Analyzing the responses to questionnaires

- Preparing the case study report.

- Contacting the two researchers who had undertaken a follow-on activity and inviting them to complete a questionnaire.

Budgen was responsible for collecting information concerning three follow-on research activities performed at Durham University. Brereton was responsible for checking the classification of responses and aggregation of information.

Participants in the case studies were asked to complete a questionnaire for each study. The questionnaire is shown in Appendix A. One mapping study had two related followon activities, but researchers were only asked to complete one form. However, issues that related to only one of the follow-on activities were identified separately when the data were analyzed.

The questionnaires used for the validation activity were based on the results of the case study. One questionnaire was based on the benefits and problems most associated with following a mapping study with another mapping study of broader scope. The other was based on the benefits and problems most associated with following a mapping study with a systematic literature review. The completed questionnaires are shown in Appendix B and Appendix C.

\subsection{Data Analysis and Interpretation}

The questionnaire responses were analyzed to summarise:

- The individual characteristics of each case, considering both the original mapping study and the follow-on activity. This allowed us to identify whether there were any contextual issues that influenced follow-on activities and also addresses subquestion 2 
- Any problems that accrue from follow-on research. This directly addresses subquestion 1.

- Any benefits that accrue from a previous mapping study.

Problems and benefits were grouped together into a reduced number of categories by one researcher (Kitchenham) and checked by another (Brereton).

When analyzing the data we separated generic benefits and problems, from benefits and problems that were case specific. For each problem we suggest some remedial action.

\section{Results}

This section reports the results of the original case study and the follow-on activities.

\subsection{Case Study Results}

The five case studies are described in Table 3 . The positive issues raised by the researchers are presented in Table 4 and the negative issues are presented in Table 5 . In terms of coverage of initial mapping study contextual factors:

- We have studies undertaken by both experienced and novice researchers.

- In none of the cases was the follow-on research activity anticipated when the initial mapping study was undertaken.

- $\quad$ Our cases include studies that extended a previous mapping study; a study that was concerned with methodology; and studies that undertook a more detailed study of the literature, and one study that was, in effect, an SLR with aggregations of primary studies at different levels of abstraction.

- With respect to involvement in the follow-on study, in three cases the follow on study was performed by the same lead researcher, in two cases it was not. However, in all cases some of the researchers were the same.

Thus our set of cases has two important limitations

- The closest we have to an example of a follow-on activity comprising a conventional SLR is the UML follow-on which aggregated outcomes of primary studies within the different mapping study categories.

- We do not have an example of a mapping study follow-on activity performed by a completely independent research group.

In terms of response to our questionnaire, two researchers out of a total of 11 did not complete the forms. By an oversight, one was not invited to complete a questionnaire. We do not know why the other researcher failed to complete the questionnaire. This affected three of the case studies because one of the researchers worked on two followon activities. It must also be noted that in several cases researchers completed forms for more than one case study. 
Table 3 Five case studies of activities following on from preceding mapping studies

\begin{tabular}{|c|c|c|c|c|c|c|c|}
\hline Studies & Original study & $\begin{array}{l}\text { Original study } \\
\text { lead } \\
\text { researcher }\end{array}$ & Follow-on Activity & $\begin{array}{l}\text { Status of } \\
\text { follow-up } \\
\text { when } \\
\text { questionnaire } \\
\text { administered }\end{array}$ & $\begin{array}{l}\text { Original lead } \\
\text { researcher still } \\
\text { involved }\end{array}$ & $\begin{array}{l}\text { Number of staff } \\
\text { involved } \\
\text { (researchers who } \\
\text { returned forms) }\end{array}$ & $\begin{array}{l}\text { Staff also } \\
\text { in first } \\
\text { study }\end{array}$ \\
\hline Tertiary Study 1 & $\begin{array}{l}\text { Mapping study of } \\
\text { SLRs based on } \\
\text { manual search of } 13 \\
\text { software } \\
\text { engineering sources } \\
\text { [36]. }\end{array}$ & $\begin{array}{l}\text { Experienced } \\
\text { researcher. } \\
\text { SLR } \\
\text { experience }\end{array}$ & $\begin{array}{l}\text { Case study aimed at investigating } \\
\text { broad versus restricted searches. }\end{array}$ & Finished & Yes & $7(6)$ & 4 \\
\hline Tertiary Study 2 & As above & As above & $\begin{array}{l}\text { Mapping study with increased } \\
\text { scope and extended time period. }\end{array}$ & Finished & Yes & $7(6)$ & 4 \\
\hline UML & $\begin{array}{l}\text { Mapping study of } \\
\text { UML empirical } \\
\text { studies [33]. }\end{array}$ & $\begin{array}{l}\text { MSc Student. } \\
\text { No SLR } \\
\text { experience }\end{array}$ & $\begin{array}{l}\text { An extended review of the UML } \\
\text { study data beyond the initial } \\
\text { 'map', intended to give a more in- } \\
\text { depth understanding of the study } \\
\text { topics and also of the forms of } \\
\text { study/participant used. In effect } \\
\text { an SLR with the aggregation of } \\
\text { primary study outcomes at } \\
\text { different levels of detail } \\
\text { depending on the available } \\
\text { primary studies in each category. }\end{array}$ & $\begin{array}{l}\text { Reporting } \\
\text { Phase }\end{array}$ & No & $4(4)$ & 4 \\
\hline Visualization & $\begin{array}{l}\text { Mapping study of } \\
\text { Visualization } \\
\text { techniques }\end{array}$ & $\begin{array}{l}\text { MSc Student. } \\
\text { No SLR } \\
\text { experience }\end{array}$ & $\begin{array}{l}\text { To investigate which forms of } \\
\text { visualization have been studied } \\
\text { most extensively and to see how } \\
\text { far the studies of the most }\end{array}$ & Conduct phase & No & $3(2)$ & 2 \\
\hline
\end{tabular}




\begin{tabular}{|c|c|c|c|c|c|c|c|}
\hline & & & $\begin{array}{l}\text { frequently studied form (structure } \\
\text { visualization) reinforce one } \\
\text { another or differ. }\end{array}$ & & & & \\
\hline Design Patterns & $\begin{array}{l}\text { Review of } \\
\text { empirical studies on } \\
\text { design patterns } \\
\text { [34]. }\end{array}$ & $\begin{array}{l}\text { PhD Student. } \\
\text { No SLR } \\
\text { experience. }\end{array}$ & $\begin{array}{l}\text { The initial follow-on activity was } \\
\text { to review of observational studies } \\
\text { on design patterns, to see what } \\
\text { insight these provided, over and } \\
\text { above those found in the original } \\
\text { study [37]. Subsequent review } \\
\text { found little additional } \\
\text { information, so the researchers } \\
\text { undertook an online survey of } \\
\text { pattern users. }\end{array}$ & Conduct phase & Yes & $2(2)$ & 2 \\
\hline
\end{tabular}

Table 4 Advantages of a Preceding Mapping Study

\begin{tabular}{|l|l|l|l|l|l|}
\hline Pros & Subtopics & $\begin{array}{l}\text { Number of } \\
\text { comments }\end{array}$ & $\begin{array}{l}\text { Number of } \\
\text { researchers }\end{array}$ & Studies & Context in which factor is applicable \\
\hline Less time consuming & & 7 & $\begin{array}{l}5 \text { (R1, R2, R3, } \\
\text { R4, R5, R6) }\end{array}$ & $\begin{array}{l}\text { UML Mapping Study } \\
\text { Tertiary Study 2 \&3 } \\
\text { Visualization Study }\end{array}$ & $\begin{array}{l}\text { Relevant to a follow-on mapping } \\
\text { study or a SLR }\end{array}$ \\
\hline $\begin{array}{l}\text { Easier to understand literature } \\
\text { and construct research } \\
\text { questions }\end{array}$ & & 10 & $\begin{array}{l}7 \text { (R1, R2, R3, } \\
\text { R4, R5, R7, R8) }\end{array}$ & $\begin{array}{l}\text { UML Mapping Study } \\
\text { Tertiary Study 2 \&3 } \\
\text { Visualization Study } \\
\text { Design Patterns }\end{array}$ \\
\hline $\begin{array}{l}\text { Only need to do automated } \\
\text { search of same time period }\end{array}$ & & 1 & R1 or a SLR \\
\hline $\begin{array}{l}\text { Previous study provided a set } \\
\text { of known studies against which } \\
\text { to assess search strings }\end{array}$ & & 2 & 2 (R1, R9) & Tertiary Study 2 & Specific. \\
\hline
\end{tabular}


14 [Type text]

14 | [Type text]

\begin{tabular}{|c|c|c|c|c|c|}
\hline $\begin{array}{l}\text { Search and selection applied to } \\
\text { both tertiary study } 2 \& 3 \\
\text { saving time }\end{array}$ & & 1 & 1 (R9) & Tertiary Study 3 & Specific \\
\hline \multirow[t]{6}{*}{$\begin{array}{l}\text { Procedure, forms and } \\
\text { experiences can be reused }\end{array}$} & $\begin{array}{l}\text { SLR protocol easy to adapt to } \\
\text { new study }\end{array}$ & 2 & 2 (R1, R9) & Tertiary Study 2 \&3 & \multirow[t]{6}{*}{$\begin{array}{l}\text { Relevant primarily to a follow-on } \\
\text { mapping study }\end{array}$} \\
\hline & $\begin{array}{l}\text { Data extraction forms reused } \\
\text { with minor changes }\end{array}$ & 2 & 2 (R1, R9) & Tertiary Study 3 & \\
\hline & $\begin{array}{l}\text { Data analysis processes } \\
\text { defined and tested. }\end{array}$ & 1 & 1 (R9) & Tertiary Study 3 & \\
\hline & $\begin{array}{l}\text { Quality criteria better } \\
\text { understood }\end{array}$ & 1 & 1 (R9) & Tertiary Study 3 & \\
\hline & $\begin{array}{l}\text { Familiarity with the process } \\
\text { made the task easier (related } \\
\text { to above) }\end{array}$ & 1 & 1 (R1) & Tertiary Study 3 & \\
\hline & $\begin{array}{l}\text { We could improve some of } \\
\text { our working practices based } \\
\text { on experiences from the } \\
\text { previous study (e.g. } \\
\text { mechanisms for recording } \\
\text { timings) }\end{array}$ & 1 & 1 (R1) & Tertiary Study 3 & \\
\hline $\begin{array}{l}\text { Results could be compared to } \\
\text { those of the previous study } \\
\text { (over a different time period). }\end{array}$ & & 1 & 1 (R1) & Tertiary Study 3 & $\begin{array}{l}\text { Relevant primarily to a follow-on } \\
\text { mapping study }\end{array}$ \\
\hline \multirow[t]{3}{*}{$\begin{array}{l}\text { Confirmation that there were } \\
\text { sufficient primary studies for } \\
\text { follow-on studies }\end{array}$} & $\begin{array}{l}\text { Confirmed availability of } \\
\text { literature to initiate further } \\
\text { study }\end{array}$ & 1 & 1 (R1) & UML Mapping Study & \multirow[t]{3}{*}{ Relevant to a follow-on SLR } \\
\hline & $\begin{array}{l}\text { Confidence that there were } \\
\text { 'clusters' that could be } \\
\text { assessed. }\end{array}$ & 1 & 1 (R1) & UML Mapping Study & \\
\hline & Identified useful cluster of & 1 & 1 (R5) & Visualization Study & \\
\hline
\end{tabular}


Final Draft Published in Information and Software Technology, 2011, 53, pp: 638-651

\begin{tabular}{|l|l|l|l|l|l|}
\multicolumn{2}{|c|}{ studies to investigate } & & & & \\
\hline $\begin{array}{l}\text { It helped identify problems and } \\
\text { difficulties (e.g. 'visualization' } \\
\text { versus 'visualisation' when } \\
\text { searching) which could be } \\
\text { addressed in the follow-on } \\
\text { study. }\end{array}$ & & 1 & 1 (R5) & Visualization Study & $\begin{array}{l}\text { Relevant to a follow-on mapping } \\
\text { study. }\end{array}$ \\
\hline $\begin{array}{l}\text { We had hoped to be able to } \\
\text { perform a fuller SLR, but in the } \\
\text { event, having identified the } \\
\text { extent of the gaps, we are } \\
\text { going to conduct an on-line } \\
\text { survey and try to enrol people } \\
\text { who use patterns. }\end{array}$ & 1 & 1 (R2) & OO Design Patterns & $\begin{array}{l}\text { Able to identify insufficient empirical } \\
\text { studies }\end{array}$ \\
\hline $\begin{array}{l}\text { Have very comprehensive } \\
\text { overview of literature }\end{array}$ & & 1 & 1 (R7) & OO Design Patterns & $\begin{array}{l}\text { Relevant to a follow-on mapping } \\
\text { study or a SLR }\end{array}$ \\
\hline
\end{tabular}

Table 5 Disadvantages of a preceding mapping study

\begin{tabular}{|c|c|c|c|c|c|}
\hline \multicolumn{2}{|l|}{ Cons } & Researcher & Study & $\begin{array}{l}\text { Context in which factor } \\
\text { is applicable }\end{array}$ & Resolution \\
\hline \multirow{2}{*}{$\begin{array}{l}\text { Problems with } \\
\text { study } \\
\text { classification }\end{array}$} & Some errors in the original classification & R1 & UML Mapping study & \multirow{2}{*}{$\begin{array}{l}\text { Relevant to a follow-on } \\
\text { mapping study or a } \\
\text { SLR }\end{array}$} & \multirow{2}{*}{$\begin{array}{l}\text { Researchers should } \\
\text { carefully review the } \\
\text { procedures and results of } \\
\text { the preceding study. }\end{array}$} \\
\hline & $\begin{array}{l}\text { The student was inexperienced with } \\
\text { visualization and had difficulty } \\
\text { classifying studies and models. }\end{array}$ & $\mathrm{R} 2$ & Visualization Study & & \\
\hline \multicolumn{2}{|c|}{$\begin{array}{l}\text { Problem expanding search due to spelling issues (modeling } \\
\text { v. modelling) }\end{array}$} & R2 & UML Mapping study & $\begin{array}{l}\text { Relevant to a follow-on } \\
\text { mapping study or a } \\
\text { SLR }\end{array}$ & $\begin{array}{l}\text { Researchers should } \\
\text { carefully review the } \\
\text { procedures and results of } \\
\text { the preceding study. }\end{array}$ \\
\hline \multicolumn{2}{|c|}{$\begin{array}{l}\text { Mapping studies catalogued papers not studies. This lead to } \\
\text { underestimating the amount of effort needed for aggregation. }\end{array}$} & R9 & UML Mapping study & $\begin{array}{l}\text { Relevant primarily to a } \\
\text { follow-on SLR }\end{array}$ & $\begin{array}{l}\text { Mapping studies should } \\
\text { identify multiple study }\end{array}$ \\
\hline
\end{tabular}


16 [ [Type text]

16 | [Type text]

\begin{tabular}{|c|c|c|c|c|}
\hline & & & & papers. \\
\hline Mapping studies missed papers found by snowballing. & R9 & UML Mapping study & $\begin{array}{l}\text { Relevant primarily to a } \\
\text { follow-on SLR }\end{array}$ & $\begin{array}{l}\text { Mapping studies need to } \\
\text { aim for completeness. } \\
\text { They should use broad } \\
\text { searches and snowballing. } \\
\text { If this is not possible for a } \\
\text { student project then a } \\
\text { student mapping study } \\
\text { should be extended as part } \\
\text { of the follow-on study. }\end{array}$ \\
\hline $\begin{array}{l}\text { The follow-up was performed some time after the original } \\
\text { mapping study, so after the first aggregation process, it was } \\
\text { decided to undertake further extractions - thus adding to the } \\
\text { elapsed time of the study. }\end{array}$ & R9 & UML Mapping study & $\begin{array}{l}\text { Relevant to a follow-on } \\
\text { mapping study or a } \\
\text { SLR }\end{array}$ & $\begin{array}{l}\text { Follow-on studies should } \\
\text { be planned to co-ordinate } \\
\text { with a mapping study. If } \\
\text { there is a gap between the } \\
\text { mapping study and follow- } \\
\text { on the follow-on should } \\
\text { included a search } \\
\text { extension. }\end{array}$ \\
\hline Detailed procedures changed - complicating analysis. & R9 & Tertiary study $2 \& 3$ & $\begin{array}{l}\text { Relevant primarily to } \\
\text { mapping studies }\end{array}$ & $\begin{array}{l}\text { Only a problem for follow- } \\
\text { on mapping studies that } \\
\text { update a previous study. } \\
\text { Researchers cannot expect } \\
\text { to stop changing processes } \\
\text { as they become more } \\
\text { effective and/or understand } \\
\text { better what they are doing. } \\
\text { They need to keep a clear } \\
\text { record of any changes and } \\
\text { be aware of their possible } \\
\text { impact. }\end{array}$ \\
\hline The time-period of the search was to June not year end - & R9 & Tertiary study $2 \& 3$ & Specific & \\
\hline
\end{tabular}


Final Draft Published in Information and Software Technology, 2011, 53, pp: 638-651

\begin{tabular}{|c|c|c|c|c|}
\hline adding a complication to inclusion criteria. & & & & \\
\hline $\begin{array}{l}\text { Writing up independent reports is difficult with respect to } \\
\text { knowing what to report about the preceding study. }\end{array}$ & R9 & Tertiary study $2 \& 3$ & $\begin{array}{l}\text { Relevant primarily to } \\
\text { mapping studies }\end{array}$ & $\begin{array}{l}\text { Consider the reporting } \\
\text { issues when preparing the } \\
\text { study protocol. }\end{array}$ \\
\hline $\begin{array}{l}\text { The follow on study is to some extent dependent upon the } \\
\text { application of the inclusion/exclusion criteria in the initial } \\
\text { mapping study. }\end{array}$ & $\mathrm{R} 4$ & Tertiary Study 2 & Specific & \\
\hline
\end{tabular}

Table 6 Reviewers comments about papers based on the follow-on activities

\begin{tabular}{|c|c|c|c|c|}
\hline Studies & Follow-on Activity & $\begin{array}{l}\text { Has a paper } \\
\text { based on the } \\
\text { follow-on } \\
\text { been } \\
\text { submitted } \\
\text { for } \\
\text { publication }\end{array}$ & $\begin{array}{l}\text { Has the paper been } \\
\text { accepted or published? }\end{array}$ & $\begin{array}{l}\text { Review comments related to the fact that the study was a follow- } \\
\text { on to a mapping study. }\end{array}$ \\
\hline \multirow[t]{2}{*}{ Tertiary Study 1} & \multirow[t]{2}{*}{$\begin{array}{l}\text { Case study aimed at investigating } \\
\text { broad versus restricted searches. }\end{array}$} & \multirow[t]{2}{*}{ Yes } & $\begin{array}{l}\text { Conference paper } \\
\text { accepted [36]. }\end{array}$ & $\begin{array}{l}\text { Thought it was clever strategy to use previous study for } \\
\text { comparison purposes. }\end{array}$ \\
\hline & & & $\begin{array}{l}\text { Journal paper second } \\
\text { submission accepted } \\
\text { after minor revisions } \\
\text { [38]. }\end{array}$ & $\begin{array}{l}\text { The comparison between the process used for the original study } \\
\text { and the process used for the follow-on study was not described } \\
\text { well enough. } \\
\text { Wanted more information from previous study. } \\
\text { Acronyms and terms were used without definition. }\end{array}$ \\
\hline Tertiary Study 2 & $\begin{array}{l}\text { Mapping study with increased scope } \\
\text { and extended time period. }\end{array}$ & Yes & $\begin{array}{l}\text { Yes [10] Two revisions } \\
\text { were required. }\end{array}$ & $\begin{array}{l}\text { First submission: Two reviewers commented that the paper was } \\
\text { difficult to understand. The separation of the mapping study into } \\
\text { three parts to include the original mapping study, the additional } \\
\text { papers found by the extended search over the same time period of } \\
\text { the original study, and the extension to the time scale of the } \\
\text { mapping study was confusing. } \\
\text { First submission: One reviewer failed to see the value of adding }\end{array}$ \\
\hline
\end{tabular}


18 [Type text]

18 [Type text]

\begin{tabular}{|l|l|l|l|l|}
\hline & & & & \\
\hline UML & $\begin{array}{l}\text { One year to the study. } \\
\text { Second submission: One reviewer wanted the distinction between } \\
\text { the initial mapping study and follow-on removed. }\end{array}$ \\
\hline $\begin{array}{l}\text { data beyond the initial 'map', intended } \\
\text { to give a more in-depth understanding } \\
\text { of the study topics and also of the } \\
\text { forms of study/participant used. In } \\
\text { effect an SLR with the aggregation of } \\
\text { primary study outcomes at different } \\
\text { levels of detail depending on the } \\
\text { available primary studies in each } \\
\text { category. }\end{array}$ & Yes & Yes [15]. & None due to preceding mapping study. \\
\hline Visualization & $\begin{array}{l}\text { To investigate which forms of } \\
\text { visualization have been studied most } \\
\text { extensively and to see how far the } \\
\text { studies of the most frequently studied } \\
\text { form (structure visualization) reinforce } \\
\text { one another or differ. }\end{array}$ & Yes & $\begin{array}{l}\text { No. It needs a major } \\
\text { revision }\end{array}$ & $\begin{array}{l}\text { Comment: The search missed papers on program comprehension. } \\
\text { (The two topics overlap and this was not recognized in the } \\
\text { original study.) }\end{array}$ \\
\hline Design Patterns & $\begin{array}{l}\text { The initial follow-on activity was to } \\
\text { review observational studies on design } \\
\text { patterns, to see what insight these } \\
\text { provided, over and above those found } \\
\text { in the original study [37]. Subsequent } \\
\text { review found little additional } \\
\text { information, so the researchers } \\
\text { undertook an online survey of pattern } \\
\text { users. }\end{array}$ & No & $\begin{array}{l}\text { Not applicable. The } \\
\text { follow-on study was an } \\
\text { opinion survey. } \\
\text { However, potential } \\
\text { respondents were } \\
\text { identified from the } \\
\text { authors of primary } \\
\text { studies found in the } \\
\text { original mapping study. }\end{array}$ & \\
\hline
\end{tabular}


In terms of the benefits of mapping studies, there were 36 reports of benefits addressing 11 separate types of benefit. However, 17 of the 36 reports related to the two benefits explicitly mentioned in the questionnaire and five of the participants did not identify any benefits other than those suggested in the questionnaire. Researcher R1 identified eight additional benefits, R9 identified six, R5 identified three, and R2 and R7 identified one each. Two of the additional benefits were specific to the particular follow-on activity, and another two were limited to updating a mapping study.

In terms of the problems associated with follow-on activities, there were 10 reports of problems corresponding to 9 individual types of problem. Seven were general problems while two were specific to a particular follow-on activity. Only four of the 11 researchers identified potential problems, with a single researcher contributing 6 of the 10 problem reports.

\subsection{Case Study Follow-on Activities}

This section discusses two additional activities we undertook to assess the validity of our original case study results.

\subsubsection{Questionnaires}

We were aware of two other examples of studies where researchers had undertaken follow-on activities after a mapping study. One we knew about because one of us (Kitchenham) participated in the research. The other we were aware of as a result of reading a published systematic literature review.

The first example was a follow-on mapping study. The original mapping study was reported in two papers ([39] and [18]). The follow-on mapping study was reported in [40]. We asked the principal researcher (Dr He Zhang) to complete the questionnaire shown in Appendix B. This questionnaire identified the benefits and problems of a follow-on mapping study based on Table 4 and Table 5, although where necessary, issues were generalised to make them less specific to the context in which they were initially reported.

Dr Zhang agreed with all the advantages identified in our case study but experienced only one of the problems we identified (i.e. detailed procedures changed, complicating analysis). He also noted an additional problem due to the wide-spread practice of writing follow-on publications. I.e. some authors published the same study in different venues (for example a conference paper followed by a journal paper) and other researchers published part of the results in one paper and further results in another paper. In some cases the original paper was found by the initial mapping study and the subsequent paper was found in the follow-on study and it was time-consuming to identify all the related papers and ensure results were reported only once in the followon mapping study. Unlike our case studies, the follow-on study was planned at the same time as the original mapping study. This may explain why Dr Zhang encountered few problems.

The second example was a follow-on systematic literature review. The original mapping study was published as a conference paper [42] which was then followed by a systematic review published in a journal [41]. We asked the principal researcher (Dr Wasif Afzal) to complete the questionnaire shown in Appendix C. This questionnaire identified the benefits and problems of a follow-on systematic literature review based on 
Table 4 and Table 5 although where necessary issues were generalised to make them less specific to the context in which they were initially reported.

Dr Afzal experienced two of the four benefits associated with follow on systematic literature reviews and none of the expected problems. He identified several additional benefits from his viewpoint as a postgraduate student:

- A mapping study can be viewed as a quality tollgate to pass before continuing to the full systematic review. In particular publishing your mapping study allows you to benefit from review comments.

- $\quad$ For PhD students, a mapping study gives an indication of how much more time to invest in for writing a full systematic review and how much research literature needs to be read.

- Writing a mapping study, gives an early idea of shortcomings in existing evidence, which becomes a basis for future studies.

- $\quad$ You get to know early about the authors who publish in your research area. (This advantage was utilised by the researchers who performed the Design Patterns mapping study. Over 800 authors of the primary studies were contacted to take part in their subsequent opinion survey.)

Overall Dr Afzal's comments were similar to the comments we obtained from students undertaking mapping studies [31].

The only problem Dr Afzal experienced was repetition between the mapping study and SLR in the study reports. Unlike our case studies, the SLR was planned at the same time as the mapping study, which may explain why he experienced few problems.

\subsubsection{Comments from Reviewers}

Comments from reviewers of papers reporting the follow-on studies are presented in Table 6. The comments from the reviewers reinforced the points made by Researcher 9 in Table 5 concerning problems analysing and reporting a study that follows on from a previous study. Among the things that reviewers found confusing were descriptions of the way in which the studies related to one another, and the detailed differences in processes between the studies.

Other issues included:

- Problems with missing papers due to a flaw in the search strategy (which was adopted from the original mapping study). This confirms the need to review the preceding study and identify any weaknesses before using it as the basis for other studies.

- Justifying the value of a follow-on study. Just because it is possible to follow-on a mapping study with a new one in a following time period, it does not imply that it is automatically useful research.

- Using jargon without explanation. Having become accustomed to certain terminology in the original mapping study, it is important not to forget than the subsequent study must be understandable as a self-standing piece of research.

\section{Discussion}

This section discusses our research questions and the study limitations. 


\subsection{RQ.S1 The advantages and disadvantages of basing research on a previous mapping study}

A summary of the generally relevant advantages and disadvantages of basing research on a preceding mapping study are summarised in Table 7 . The issues have been reworded slightly to make them understandable outside the context of the specific studies. (Note we have also included the problem of full reporting of the primary studies' references and classifications pointed out in Section 2.1.)

In the original case study [11], most researchers agreed that the use of a preceding mapping study both saved time for subsequent studies and provided an understanding of the literature. However, they noted a number of other advantages:

- In the case of an extension to a mapping study, the protocol may be reusable; if the same researchers undertake the study they will be experienced with the procedures; time trends can be investigated; and a set of known studies exists which can be used to validate search strings used for automated searches.

- The mapping study can identify clusters of research studies that are suitable for more detailed study.

- The mapping study may identify the need for more primary studies.

- The researchers themselves gain a very good overview of the literature.

The validation examples confirmed the advantages expected for the type of study although Dr Afzal did not find the preceding mapping study made the follow-on less time consuming nor that it helped him to understand the literature and construct research questions. In addition, Dr Afzal identified a number of other advantages from his viewpoint of a research student confirming the educational value of mapping studies.

In the original case study [11], researchers identified fewer disadvantages than advantages and one case (the follow-on from the Design Patterns study) reported no disadvantages. The validation examples confirmed that in the case of the same lead researcher undertaking the follow-on examples, there are few problems. Nonetheless some important problems were identified:

- If the search process used by the original mapping study was restricted, there are likely to be limitations to the original study that will negatively impact subsequent research activities. For example in two of our cases the searches were restricted because the original mapping studies were MSc projects that needed to be completed in a short time period. A particular problem that can occur in this situation is missing primary studies due either to search string limitations or lack of snowballing for extra studies. In addition, the classification scheme may be over-simplistic or incorrectly used.

- If the follow-on research activity is an extension of the preceding mapping study, it is important to be aware of process changes that could reduce the comparability of the initial and follow-on mapping studies.

- Mapping studies may underestimate the number of primary studies needed for subsequent SLRs. This occurs when multiple primary studies are reported in a single paper. This is of particular importance if a mapping study is being used as a means to assist resource estimation for future SLRs. It is equally important to be sure that the policy for dealing with duplicate reports of the same study is appropriate i.e. whether duplicate reports have been identified and appropriately handled. For example, neither the Jørgensen and Shepperd mapping study [16], 
nor the Sjøberg et al. [17] mapping study, removed primary studies that reported the same study. This may be acceptable for a mapping study but might not be so for a follow-on activity, particularly an SLR.

- If follow-on activities are delayed, even a high quality mapping study will need to be brought up to date before the follow-on research can be started.

- Reporting the results of follow-on studies may be difficult if it is necessary to report clearly the links between the two studies, while still ensuring that the following study can be reported as a self-standing piece of work.

In both of the validation examples, the follow-on study was planned when the original mapping study took place and the lead researcher remained the same for the follow-on study. These may be the reasons why the lead researchers reported few problems. However, the two validation examples suggested that there could be problems with procedures changing and repetition when reporting the follow-on study.

The comments from reviewers strongly confirmed the problems with reporting followon activities clearly, both because of procedural changes and because the relationship between the individual studies may be complicated.

\subsection{RQ.S2 What makes a mapping study suitable for supporting further research activities}

We have already noted that a mapping study cannot readily support further research activities, except by the original researchers, unless all the references are cited and the classification information for each study is reported. An additional issue is that the mapping study must be of high quality. It must have been based on:

- A stringent search process including automated searches, manual searches of critical sources (particularly topic-specific conferences), snowballing of primary study references, and direct communication with important researchers and research groups.

- A well-defined and reliable classification system.

If the study is not known to be of high quality, or is known to have been undertaken in a restricted timescale, the mapping study report needs to be reviewed critically to confirm its suitability as a basis for further research activities. In the event that the mapping study is not of sufficient quality, it should be used as the starting point for a more detailed mapping study. In particular, it will provide a list of known primary studies against which subsequent searches and automated search strings can be validated.

\subsection{RQ How do studies contribute to further research?}

If a high quality fully reported mapping study has been performed, there are many ways in which the outcomes can be used, in addition to undertaking conventional SLRs based on clusters of related primary studies. A high quality mapping study can be used as:

- A baseline against which research trends can be tracked over time.

- A justification for further primary studies when there are few (or no) relevant empirical studies.

- As a means of identifying relevant literature for the "related research" section in other primary studies.

- A baseline for empirical research of various kinds. 
- A set of known references which other mapping studies and SLRs can use to validate their own searches.

- An education resource.

\subsection{Study Limitations}

Our original study [11] had several weaknesses:

- We adopted a participant-observer the case study approach to ensure that we were systematic during our data collection and data analysis activities and could demonstrate traceability from our data to our conclusions. However, our approach can be criticised as being little more than a "lessons learnt" approach. In particular, the data came from mapping studies and follow-on activities undertaken by EPIC team members. This might introduce bias because we are generally in favour of systematic mapping studies and might be more likely to report benefits than problems.

- The questionnaire was very simple but the positive and negative questions were slightly unbalanced. The question related to benefits offered some examples, which were readily accepted by most of the respondents whereas the question related to problems did not have any examples.

To address some of these limitations we undertook two validation activities. In particular, we elicited information about two other studies, both based on a preceding mapping study, from principal researchers not associated with the EPIC project. Furthermore, the questionnaires used for this validation activity identified both possible benefits and possible problems related to the specific follow-on activity, and so was more balanced. We also looked for additional problems by consulting the referee reports obtained when we attempted to publish the results of the follow-on studies. This allowed us to confirm some of the potential problems from another source.

The most important remaining limitations are that we have relatively few cases and that our case studies and validation examples are restricted to studies where researchers involved in an initial mapping study were also involved in the subsequent research activity (although the lead researcher changed in two cases). The validation examples strongly confirmed that problems are minimal if a follow-on study has the same lead researcher. However, if researchers base their work on someone else's mapping study, we would expect problems, if they occur, to be more severe. For example, Beecham [43] needed to undertake a very detailed comparison to understand why a mapping study she performed found a different set of primary studies to those found by another mapping study with the same basic research question.

\section{Conclusions}

Table 7 presents a summary of the major benefits and problems with basing research on a preceding mapping study. It indicates that mapping studies can be of significant benefit to researchers in establishing baselines for further research activities. Such a baseline can be used in a variety of ways, either as the starting point for investigating research trends, or as the starting point for conventional SLRs. However, for each benefit there are corresponding problems that can arise if the original mapping study is not of very high quality in terms both of fully reporting the results, and of the adopting a rigorous search process. 
Table 7 Summary of the benefits and problems of basing follow-on research on software engineering mapping studies

\begin{tabular}{|c|c|}
\hline Benefits & Problems \\
\hline \multirow[t]{2}{*}{$\begin{array}{l}\text { Reduces the time required for the follow-on } \\
\text { activity. }\end{array}$} & $\begin{array}{l}\text { If there is a time lag between the follow- } \\
\text { on activities another search may be } \\
\text { necessary adding to the time and effort } \\
\text { required for the follow-on activity. }\end{array}$ \\
\hline & $\begin{array}{l}\text { If the search was restricted in any way, a } \\
\text { broader search will be required if the } \\
\text { follow-on activity is an SLR. }\end{array}$ \\
\hline $\begin{array}{l}\text { Makes it easier for researchers to } \\
\text { understand the literature and construct } \\
\text { research questions. }\end{array}$ & \multirow{2}{*}{$\begin{array}{l}\text { If the individual papers are not fully } \\
\text { referenced and there is no clear link } \\
\text { between each papers its classification, the } \\
\text { results of the mapping study may be of } \\
\text { limited value. }\end{array}$} \\
\hline $\begin{array}{l}\text { Can provide a comprehensive overview of } \\
\text { the literature. This may be of particular } \\
\text { importance to new researchers who can get } \\
\text { an overview of how much literature needs to } \\
\text { be read, and who are the important } \\
\text { researchers in their field of interest. }\end{array}$ & \\
\hline $\begin{array}{l}\text { Provides confirmation that sufficient } \\
\text { primary studies exist for follow-on SLRs. }\end{array}$ & \multirow{2}{*}{$\begin{array}{l}\text { Basing mapping studies on papers, not } \\
\text { individual studies (as required for SLRs), } \\
\text { means that papers reporting the same } \\
\text { study and papers reporting multiple } \\
\text { studies will not be clearly identified. This } \\
\text { means the number of papers may be a } \\
\text { poor indication of the number of primary } \\
\text { studies. }\end{array}$} \\
\hline $\begin{array}{l}\text { May indicate that more primary studies are } \\
\text { needed. }\end{array}$ & \\
\hline $\begin{array}{l}\text { Procedures, forms and experiences can be } \\
\text { reused. }\end{array}$ & $\begin{array}{l}\text { Detailed procedures may change as a } \\
\text { result of problems experienced in the } \\
\text { initial mapping study. This may make } \\
\text { comparisons between the original study } \\
\text { and the follow-on study difficult to report } \\
\text { accurately and may make the results } \\
\text { difficult to interpret. }\end{array}$ \\
\hline $\begin{array}{l}\text { Results from the original study can act as a } \\
\text { baseline for comparison with the results of } \\
\text { the follow-on study. }\end{array}$ & $\begin{array}{l}\text { The follow-on study must stand as a } \\
\text { research paper in its own right. }\end{array}$ \\
\hline $\begin{array}{l}\text { Flaws with the original study can be } \\
\text { avoided in the following research. }\end{array}$ & $\begin{array}{l}\text { Flaws with the original study may also } \\
\text { affect the follow-on research. }\end{array}$ \\
\hline $\begin{array}{l}\text { Even a poor quality mapping study can } \\
\text { provide a set of known primary studies that } \\
\text { can be used to validate subsequent search } \\
\text { strings and search results. }\end{array}$ & $\begin{array}{l}\text { If the original mapping study was of poor } \\
\text { quality, the entire search process may } \\
\text { need to be redone. }\end{array}$ \\
\hline
\end{tabular}

In particular, it is important to recognize that although mapping studies may claim to follow a rigorous research process, not all follow the process closely enough to ensure that their results are trustworthy. In particular, although undertaking mapping studies may provide a useful educational experience for MSc students [31], the outcomes of 
mapping studies performed under the time and effort restrictions that this may impose on students may be limited. Thus, researchers intending to use a preceding mapping study as the basis for further research must take care to critically review the quality and suitability of the mapping study research procedures before depending on its results.

Another problem arises when reporting results of the subsequent study. The relationship between the two studies needs to be clearly reported without impacting the readability of the follow-on study. Furthermore the follow-on study needs to be reported as a selfstanding research activity without relying on readers already knowing about the preceding study.

A major limitation of our study is that we have not seen any examples of researchers making use of initial mapping studies undertaken by other researchers. Such a procedure offers considerable potential for making our research more effective, if mapping studies can provide researchers with an overview of current research topics and/or can be the basis of subsequent systematic reviews or primary studies. It would also be useful for students and practitioners if our text books and international standards began to use the results of mapping studies and SLRs. However, at the moment, it seems that, although mapping studies are encouraging follow-on studies, the researchers who are benefitting are mainly the researchers who performed the original mapping studies, rather than the research community as a whole.

Although we have addressed the value of mapping studies for follow-on research, there are two issues we have not addressed: the value of mapping studies to practitioners and the value of mapping studies in their own right. Although mapping studies may offer value to researchers, they appear to offer little value to practitioners. Petersen et al. [13] suggest that visual representations of research maps are useful to practitioners, but as yet there is no supporting evidence. Mapping studies may also be of benefit to practitioners indirectly as the basis of subsequent SLRs or by being used as the basis for improved text books and standards, but again there is currently no evidence to support these suggestions. In fact, contradicting our previous speculation, the follow-on study that came closest to an SLR offered recommendations only to researchers [15].

It is also important that individual mapping studies are valuable research outcomes in their own right. With respect to the two studies discussed in Section 2.2, we believe the mapping studies produced by Sjøberg et al. [17] and Jørgensen and Shepperd [16] are excellent examples of mapping studies that deliver value to researchers irrespective both of any follow-on activities and of the fact that the scope of their searches was restricted (one used a restricted set of sources, the other was restricted to journal papers). However, this is not the case for all software engineering mapping studies. For mapping studies to be valuable in their own right they must say something interesting about the state of research in a topic area that is of importance to researchers working in that area. Simple counts of information extracted from publication details are not in themselves of much scientific value.

Finally, given the increasing publication rate of mapping studies and the limitations of this study, we believe it is important for other independent researchers to investigate the value of mapping studies in software engineering research. 


\section{Acknowledgements}

This work was funded through EPSRC award EP/E046983 (EPIC). We would like to thank all those who helped with this by providing their responses to our questionnaires particularly Dr Afzal and Dr Zhang.

\section{References}

[1] Dybå, T., Kitchenham, B. and Jørgensen, M. (2005) Evidence-based Software Engineering for Practitioners, IEEE Software, 22 (1) January, 2005, pp58-65.

[2] Jørgensen, M., Dybå, T. and Kitchenham, B.A. (2005) Teaching Evidence-Based Software Engineering to University Students, 11th IEEE International Software Metrics Symposium (METRICS'05), p. 24.

[3] Kitchenham, B., Dybå, T. and Jørgensen, M. (2004) Evidence-based Software Engineering. Proceedings of the 26th International Conference on Software Engineering, (ICSE '04), IEEE Computer Society, Washington DC, USA, pp $273-281$.

[4] Khan, Khalid, S., Kunz, Regina, Kleijnen, Jos and Antes, Gerd. 2003 Systematic Reviews to Support Evidence-based Medicine, The Royal Society of Medicine Press Ltd.

[5] Kitchenham, B.A. and Charters, S. (2007) Guidelines for performing Systematic Literature Reviews in Software Engineering Technical Report EBSE-2007-01.

[6] Petticrew, M. and Roberts, H. (2005) Systematic Reviews in the Social Sciences: A Practical Guide, Blackwell Publishing.

[7] Budgen, D., Bailey, J., Turner, M., Kitchenham, B., Brereton, P. and Charters, S. (2009) A cross-domain investigation of empirical practices. IET Software, 3(5), pp 410-421.

[8] Brereton, O. P., Kitchenham, B.A. (2009) The Scope of EPIC Case Studies. EPIC technical Report EPIC-2007-01.

[9] Budgen, D., Turner, M., Brereton, P. and Kitchenham, B. (2008b) "Using Mapping Studies in Software Engineering”, Proceedings of PPIG 2008, Lancaster University, pp. 195-204.

[10] Kitchenham, B., Pretorius, R., Budgen. D., Brereton, P., Turner, M., Niazi, M., and Linkman, S.G., (2010) Systematic Literature Reviews in Software Engineering - A Tertiary Study. Information and Software Technology, 52(8), pp 934-944.

[11] Kitchenham, B., Budgen, D., and Brereton, P. (2010) The value of mapping studies - A participant observer case study. Proceedings of EASE 2010, BCS eWic.

[12] Jørgensen, M. (2004) A review of studies on expert estimation of software development effort, Journal of Systems and Software, 70 (1-2), pp37-60.

[13] Petersen, K., Feldt, R., Mujtaba, S. and Mattsson, 2008. M. Systematic mapping Studies in Software Engineering. Proceedings EASE 08, BCS eWIC

[14] Kitchenham, B.A. (2010) What's up with metrics? - A preliminary mapping study. Journal of Systems and Software, 83(1), pp 37-51.

[15] Budgen , D., Burn, A.J., Brereton, O.P., Kitchenham, B.A., and Pretorius, R. (2010) Empirical evidence about the UML: a systematic literature review. Softw. Pract. Exper. Accepted for publication, doi: 10.1002/spe1009.

[16] Jørgensen, M., and Shepperd, M. (2007) A Systematic Review of Software Development Cost Estimation Studies, IEEE Transactions on SE, 33(1), pp3353. 
[17] Sjøberg, D.I.K., Hannay, J.E., Hansen, O., Kampenes, V.B., Karahasanovic, A., Liborg, N.K. and Rekdal, A.C. (2005) A survey of controlled experiments in software engineering. IEEE Transactions on SE, 31 (9), pp.733-753.

[18] Zhang, H., Kitchenham, B., Pfahl, D. (2008) Software process simulation modeling: Facts, trends, and directions. In: Proceedings of 15th Asia-Pacific Software Engineering Conference (APSEC'08), Beijing, China, IEEE Computer Society, pp. 59-66

[19] Dybå, T., Kampenes, V.B. and Sjøberg, D.I.K. (2006) A systematic review of statistical power in software engineering experiments, Information and Software Technology, 48(8), pp 745-755.

[20] Hannay, J. and Jørgensen, M. (2008) The Role of Deliberate Artificial Design Elements in Software Engineering Experiments, IEEE Trans. on Software Eng., 34(2), pp. 242-259.

[21] Hannay, J E., Sjøberg, D.I.K and Dybå. T. (2007) A Systematic Review of Theory Use in Software Engineering Experiments. IEEE Trans on SE, 33 (2), 2007, pp 87-107.

[22] Kampenes, V.B., Dybå, T., Hannay. J.E. and Dag I. K. Sjøberg. (2007) A Systematic Review of Effect Size in Software Engineering Experiments, Information and Software Technology, 49 (11-12), pp. 1073-1086.

[23] Kampenes, V.B., Dybå, T., Hannay. J.E. and Dag I. K. Sjøberg. (2009) A Systematic Review of Quasi-Experiments in Software Engineering, Information and Software Technology, 51 (1), pp. 71-82.

[24] Bailey, J., Budgen, D., Turner, M., Kitchenham, B., Brereton, P. and Linkman, S. (2007) Evidence relating to Object-Oriented software design: A survey, in 'Proceedings of Empirical Software Engineering \& Measurement, 2007', IEEE Computer Society Press, pp. 482-484.

[25] Gómez, O., Oktaba, H., Piattini, M. and García, F. (2006) A Systematic Review Measurement in Software Engineering: State-of-the-Art in Measures, ICSOFT 2006, CCIS 10, pp. 165-176

[26] Bellini, C.G., Pereira, R.D.C.D.F. and Becker, J.L. (2008) Measurement in Software Engineering from the Roadmap to the Crossroads. International Journal of Software Engineering and Knowledge Engineering, 18(1), pp. 37-64.

[27] Catal, C. and Diri, B. (2009) A systematic review of software fault prediction studies, Expert Systems with Applications. 36, pp. 7346-7354.

[28] Kitchenham, B., Brereton, O.P., Budgen, D., Turner, M., Bailey, J. and Linkman, S. (2009a) Systematic Literature reviews in software engineering - a systematic literature review. Information and Software Technology, 51, pp 7-15.

[29] Neto, A.D., Subramanyan, R., Viera, M., Travassos, G.H. and Shull, F. (2008) Improving Evidence about Software Technologies. A Look at model-based testing. IEEE Software, 25(6), pp $242-249$.

[30] Kitchenham, B.A., Mendes, E. and Travassos, G.H. Cross versus withincompany cost estimation studies: A systematic review. IEEE Transactions on Software Engineering, 33(5), 2007, pp. 316-329.

[31] Kitchenham, B., Brereton, P., and Budgen, D. (2010) The Educational Value of Mapping Studies of Software Engineering Literature. ICSE 2010 Education Theme. South Africa, ACM Press, pp 1-7.

[32] Wieringa, R., Maiden, N.A.M, Mead, N.R. and Rolland, C. (2006) Requirements engineering paper classification and evaluation criteria: a proposal and a discussion. Requirements Engineering, 11(1), pp 102-107.

[33] Pretorius, R. and Budgen, D. (2008) A mapping study on empirical evidence related to the models and forms used in the UML, in 'Proceedings of 2nd ACM- 
IEEE International Symposium on Empirical Software Engineering and Measurement, ESEM 2008, ACM Press, pp. 342-344.

[34] Zhang, C. and Budgen, D. (2010) What do we know about the effectiveness of Software Design Patterns. Manuscript under review.

[35] Yin, Robert K. (2003) Case Study Research: Design and Methods, 3rd Edition, Sage Publications.

[36] Kitchenham, B., Brereton, P., Turner, M., Niazi, M., Linkman, S.G., Pretorius, R. and Budgen. D. (2009b). The Impact of Limited Search Procedures for Systematic Literature Reviews-An Observer-Participant Case Study”, Proceedings of ESEM 2009, IEEE CS Press.

[37] Budgen, D. and Zhang, C. (2009) Preliminary Reporting Guidelines for Experience Papers, Proceedings of EASE 2009, BCS eWiC.

[38] Kitchenham, B., Brereton, P., Turner, M., Niazi, M., Linkman, S.G., Pretorius, R. and Budgen. D. (2010) Refining the systematic literature review process - two participant observer case studies. 15, pp. 618-653.

[39] Zhang, H., Kitchenham, B., Pfahl, D. (2008) Reflections on 10 years of software process simulation modelling: A systematic review. In: Proceedings of International Conference on Software Process (ICSP'08). Volume LNCS 5007., Leipzig, Germany,Springer-Verlag pp. 345-365.

[40] Zhang, H., Kitchenham, B. and Phahl, D. (2010) Software Process Simulation Modeling: An Extended Systematic Review. International Conference on Software Process ICSP 2010.

[41] Afzal, W., Torker, R. and Feldt, R. (2009) A systematic review of search-based testing for non-functional system properties. Information and Software Technology 51(6), pp 957-976.

[42] Afzal, W., Torker, R. and Feldt, R. (2008) A systematic mapping study on nonfunctional search-based software testing, in: 20th International Conference on Software Engineering and Knowledge Engineering (SEKE).

[43] Beecham, S. (2009) A short comparison of two systematic literature reviews on fault prediction. University of Hertfordshire Technical Report UH-CS-TR-492.

\section{Appendix A: Questionnaire}

Name:

Topics of original mapping study:

1. Was the follow-on study anticipated when the mapping study was performed: Yes/No/Don't Know

2. Is the follow-on study completed or not? Yes/No

If No, what stage are you at.

3. Were there any problems working from the mapping study? Yes/No

If Yes, what were they, and do you have any idea how they could be avoided?

4. Were there any clear benefits from having a preliminary mapping study? Yes/No

If Yes, please specify all benefits

o Less time consuming (searches and classification done) Yes/No

0 Easier to understand the basic literature and construct research questions Yes/No

o Other (please specify) 


\section{Appendix B Questionnaire concerning the benefits and problems of research activities following on from a preceding mapping study}

1. Was the follow-on mapping study planned at the same time as the original mapping study? Yes/No

2. The following table identifies possible benefits that accrue to a mapping study that follows-on from a preceding mapping study. Please identify which if any benefits applied in your own experience.

\begin{tabular}{|l|l|l|}
\hline Possible Benefits & $\begin{array}{l}\text { Experienced in your } \\
\text { follow-on research study }\end{array}$ & $\begin{array}{l}\text { Optional Comments } \\
\text { That's due to the improved } \\
\text { productivity and domain } \\
\text { knowledge }\end{array}$ \\
\hline $\begin{array}{l}\text { Less time consuming } \\
\begin{array}{l}\text { Easier to understand literature and } \\
\text { construct research questions }\end{array}\end{array}$ & Yes/No & $\begin{array}{l}\text { Actually, we follow up the } \\
\text { same RQs defined in Stage 1. }\end{array}$ \\
\hline $\begin{array}{l}\text { Previous study provided a set of } \\
\text { known studies against which to } \\
\text { assess search strings }\end{array}$ & Yes/No & $\begin{array}{l}\text { The two stages of MP used } \\
\text { different search strategies, the } \\
\text { results from manual search } \\
\text { (Stage 1) definitely contribute } \\
\text { to the construction of search } \\
\text { string used for Stage 2. }\end{array}$ \\
\hline $\begin{array}{l}\text { Procedure, forms and experiences } \\
\text { can be reused }\end{array}$ & Yes/No & $\begin{array}{l}\text { Some procedures, and } \\
\text { experiences can be reused in } \\
\text { our case. But as the different } \\
\text { search strategies were used, } \\
\text { there also exist some } \\
\text { differences. }\end{array}$ \\
\hline $\begin{array}{l}\text { Have very comprehensive } \\
\text { overview of literature }\end{array}$ & $\begin{array}{l}\text { Although most of issues had } \\
\text { been solved in Stage 1, which } \\
\text { improved Stage 2's efficiency, } \\
\text { we encountered a small number } \\
\text { of new issues. }\end{array}$ \\
\hline $\begin{array}{l}\text { Misunderstanding and problems } \\
\text { found in the preceding mapping } \\
\text { following study was more } \\
\text { efficient } \\
\text { those of the previous study }\end{array}$ & Yes/No & $\begin{array}{l}\text { It is one purpose of our original } \\
\text { plan of conducting a staged MP }\end{array}$ \\
\hline Yes/No & $\begin{array}{l}\text { We have more confidence } \\
\text { about the review/analysis } \\
\text { results and the holistic state-of- } \\
\text { the-art. }\end{array}$ \\
\hline
\end{tabular}

3. Were there any other benefits? If Yes please specify: 
4. The following table identifies possible problems that accrue to a mapping study that follows-on from a preceding mapping study. Please identify which if any problems applied in your own experience.

\begin{tabular}{|c|c|c|}
\hline Possible Problems & $\begin{array}{l}\text { Experienced in your } \\
\text { follow-on research } \\
\text { study }\end{array}$ & Optional Comments? \\
\hline $\begin{array}{l}\text { Problems with study classification due to } \\
\text { inconsistence/errors in initial mapping } \\
\text { study }\end{array}$ & Yes/No & $\begin{array}{l}\text { In Stage 2, we enriched } \\
\text { the options for } \\
\text { particular questions, } \\
\text { but found no need to } \\
\text { change classification }\end{array}$ \\
\hline $\begin{array}{l}\text { Mapping studies missed papers found by } \\
\text { other methods such as snowballing }\end{array}$ & Yes/No & $\begin{array}{l}\text { The search scope of } \\
\text { Stage } 1 \text { is explicit and } \\
\text { clear, and we used } \\
\text { manual search. So there } \\
\text { was no missing study } \\
\text { in the preceding scope } \\
\text { found during Stage } 2 \text {. }\end{array}$ \\
\hline $\begin{array}{l}\text { The follow-up was performed sometime } \\
\text { after the original mapping study, so further } \\
\text { searches of the previously searched sources } \\
\text { were required - thus adding to the elapsed } \\
\text { time of the study. }\end{array}$ & Yes/No & $\begin{array}{l}\text { In our case, there is no } \\
\text { need to repeat any } \\
\text { portion of previous } \\
\text { search. But warming- } \\
\text { up may take a bit time } \\
\text { after more than a half } \\
\text { year break. }\end{array}$ \\
\hline $\begin{array}{l}\text { Detailed procedures changed - } \\
\text { complicating analysis }\end{array}$ & Yes/No & $\begin{array}{l}\text { The search process was } \\
\text { changed, but the data } \\
\text { collection and synthesis } \\
\text { remained almost the } \\
\text { same. The comparison } \\
\text { makes the analysis a bit } \\
\text { more complicated. }\end{array}$ \\
\hline $\begin{array}{l}\text { Writing up independent reports is difficult } \\
\text { with respect to knowing what to report } \\
\text { about the preceding study. }\end{array}$ & $\begin{array}{l}\text { Yes/No } \\
\text { N/A }\end{array}$ & $\begin{array}{l}\text { Given the RQs and } \\
\text { plan, the two stages MS } \\
\text { won't produce } \\
\text { 'independent reports'. } \\
\text { Instead, we intended to } \\
\text { produce a } \\
\text { comprehensive report } \\
\text { by integrating two } \\
\text { stages results. }\end{array}$ \\
\hline
\end{tabular}

5. Were there any other problems? If Yes Please specify

One problem we experienced in Stage 2 is to identify the continuous and duplicate published studies between two stages. It is a time-consuming step, because the reviewer has to go over most studies identified in Stage 1 to find the difference. In our case, almost a quarter of studies found by Stage 2 search were finally excluded as being 'continuous' or 'duplicate' studies. 


\section{Appendix C Questionnaire concerning the benefits and problems of research activities following on from a preceding mapping study}

1. Was the follow-on systematic literature review planned at the same time as the original mapping study? Yes

2. The following table identifies possible benefits that accrue to a systematic literature review that follows-on from a preceding mapping study. Please identify which if any benefits applied in your own experience.

\begin{tabular}{|l|l|l|}
\hline Possible Benefits & $\begin{array}{l}\text { Experienced in your } \\
\text { follow-on research study }\end{array}$ & Optional Comments \\
\hline Less time consuming & No & \\
\hline $\begin{array}{l}\text { Easier to understand literature and } \\
\text { construct research questions }\end{array}$ & No & \\
\hline $\begin{array}{l}\text { Confirmation that there were } \\
\text { sufficient primary studies for } \\
\text { follow-on studies. }\end{array}$ & Yes & \\
\hline $\begin{array}{l}\text { Have very comprehensive } \\
\text { overview of literature }\end{array}$ & Yes & \\
\hline
\end{tabular}

3. Were there any other benefits? If Yes please specify:

i) I see the mapping study as a quality tollgate to pass before continuing to the full systematic review; especially publishing your mapping study helps you to incorporate any changes from reviewers' comments.

ii) As a PhD student, a mapping study gives you an idea of how much more time to invest in for writing a full systematic review, since surely, being a $\mathrm{PhD}$ student, you do not want to keep reading others' papers for too long.

iii) By writing a mapping study, you have an early idea of shortcomings in existing evidence, which becomes a basis for future studies.

iv) You get to know early about the authors who publish in your research area.

4. The following table identifies possible problems that accrue to a systematic review that follows-on from a preceding mapping study. Please identify which if any problems applied in your own experience. 
32 | [Type text]

$32 \mid$ [Type text]

\begin{tabular}{|l|l|l|}
\hline Possible Problems & $\begin{array}{l}\text { Experienced in your } \\
\text { follow-on research } \\
\text { study }\end{array}$ & Optional Comments? \\
\hline $\begin{array}{l}\text { Mapping studies missed papers found by } \\
\text { other methods such as snowballing }\end{array}$ & No & \\
\hline $\begin{array}{l}\text { The follow-up was performed sometime } \\
\text { after the original mapping study, so further } \\
\text { searches of the previously searched sources } \\
\text { were required. }\end{array}$ & No & No \\
\hline $\begin{array}{l}\text { Mapping study catalogued papers not } \\
\text { studies. This lead to underestimating the } \\
\text { amount of effort needed for data } \\
\text { extraction/aggregation. }\end{array}$ & Noraring study had \\
\hline
\end{tabular}

5. Were there any other problems? If Yes Please specify

i) There can be some repetition of work in the review that is already published in the mapping study. 